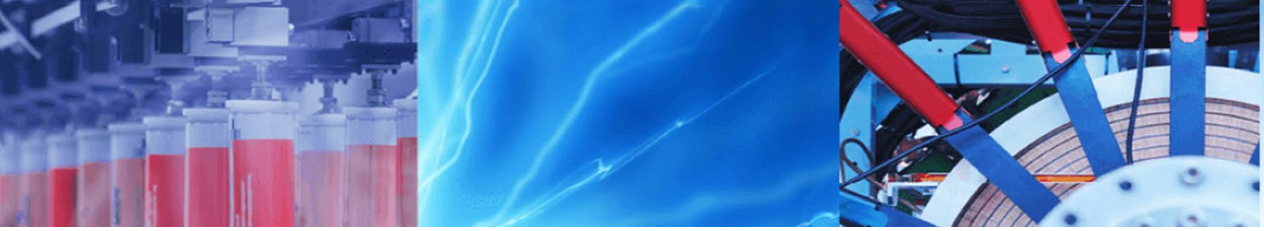

Research Article

\title{
Kinetic studies on adsorption behavior of methyl orange using modified halloysite, as an eco-friendly adsorbent
}

\author{
Davut Lacin $^{1} \cdot$ Ayse Z. Aroguz ${ }^{2}$ (D)
}

Received: 13 August 2020 / Accepted: 29 October 2020 / Published online: 27 November 2020

(c) Springer Nature Switzerland AG 2020

\begin{abstract}
In this work, modified halloysite was successfully prepared and its adsorptive capacity was studied using methyl orange dye solution. The adsorption behavior was systematically performed as a function of initial dye concentration and time. The halloysite-mineral $\left(\mathrm{Al}_{2} \mathrm{O}_{3} \cdot 2 \mathrm{SiO}_{2} \cdot 4 \mathrm{H}_{2} \mathrm{O}\right)$ used in this study was an aqueous alumino silicate mineral consisting of layers with similar structural composition and was gathered from the Biga Peninsula, Western Anatolia. Characterization of the prepared material was examined using scanning electron microscopy (SEM), Fourier transform infrared spectroscopy (FTIR), X-ray diffraction (XRD) and Differential Thermal Analyzer (DTA). The adsorptive capacity of the modified halloysite in methyl orange was increased by increasing the contact time and initial dye concentration. Lagergren pseudo first-order and pseudo second-order kinetics were performed and pseudo second-order model was found to be the best fit model for the adsorption kinetic. Langmuir, Freundlich, Sips and Dubinin-Radushkewich isotherm models were applied to the experimental data to find the suitable model for describing the adsorption equilibrium. Unmodified-clay was also used in the adsorption process of methyl orange to compare the adsorptive property of the modified-clay. It was found that modified halloysite performed better as an adsorbent than untreated clay for the adsorption of methyl orange.
\end{abstract}

Keywords Methyl orange $\cdot$ Halloysite $\cdot$ Modified clay $\cdot$ Adsorption $\cdot$ Kinetic

\section{Introduction}

Effective and low-cost technologies are necessary when removing contaminants from wastewater [1-3]. Some of such techniques are already widely used to purify industrial effluents before or after discharging them to the environment. Among these effluents, dyes come up as being one of the most important pollutants, possessing complex aromatic molecular structures with a synthetic origin $[4,5]$. Synthetic dye pollutants from various industries, paper, textiles, plastics, rubber, leather, cosmetics, pharmaceutics and printing are highly toxic, carcinogenic and barely biodegradable [6]. The discharge of dyes along with industrial wastewaters to natural streams can pose a risk to the environment. Dyes in water are stable to light and reduce light penetration when it is dispersed on the surface of water or spread inside the aquatic medium. They also reduce the photosynthesis of the aquatic plants $[7,8]$. Methyl orange $(\mathrm{MO})$ is an anionic dye, which belongs to the azo dye group and is commonly used within many industries, highly hazardous and can have harmful effects on the environment $[9,10]$. There are many review articles on the removal of dyes and pigments in effluents because of their such hazardous nature [5, 11-14]. Many techniques such as flocculation, oxidation, coagulation, adsorption, precipitation, ion exchange, filtration, ozonisation, aerobic and anaerobic degradation are suggested to remove dye pollutants from wastewater [8-10]. The best method is to remove the pollutant dye before discharging

$\triangle$ Ayse Z. Aroguz, aroguz@istanbul.edu.tr| ${ }^{1}$ Department of Geological Engineering, Faculty of Engineering, Istanbul University-Cerrahpasa, 34850 Istanbul, Turkey. ${ }^{2}$ Department of Chemistry, Faculty of Engineering, Istanbul University-Cerrahpasa, 34850 Istanbul, Turkey. 
it to the environment [15] and adsorption stands out as being one of the most preferred and effective processes for wastewater treatment, especially for dye removal, in terms of cost, simplicity of design, ease of use [16]. Different kinds of adsorbents are used for the adsorption process with activated carbon $[7,9]$ and clay $[17,18]$ being highly popular.

Many researchers have concentrated on finding low cost, eco-friendly and natural adsorbents such as fly ash [19], industrial solid waste [20], biomaterials [15] zeolites [21, 22] and so forth. However, despite the utility of natural clay for the adsorption process, they are not always very effective for dye adsorption as it often is necessary to modify the clay surface [23]. Clays can be modified with surfactants to improve their adsorption performance which are then called organoclays. Halloysite is a clay mineral belonging to the silicate group and is formed within the melting cavities of clayey limestones, which are created by the alteration of the magmatic depth, magmatic volcanic and/or metamorphic rocks which include minerals such as mica and feldspar. In terms of colour they can be white, light bluish-green, bluish-gray while being glassy in appearance and possessing a conchoidal fracture surface [24-26]. Halloysite with a large surface area having layer and hollow structure shows excellent physical properties and chemical stability [27-32]. The geometrical characterization of halloysite nanotubes show polydispersity property due to their geological origin [30]. Lazzara and his coworkers deeply investigated halloysite polydispersity property, consequently the adsorption capacity of the nanotubes. Halloysite nanotubes are commonly used as adsorbent for the decontamination purposes due to their natural biocompatible and nontoxic properties and also abundantly, inexpensively available [29-31]. In addition, Cavallaro and his coworkers used natural halloysite clay to fabricate inexpensive low-cost reverse inorganic micelles to trap the hydrophilic antibacterial agents efficiently [31]. Chen and coworkers proposed that the halloysite clay is an effective adsorbent for the removal of an anionic dye (as $\mathrm{MO}$ ) due to positive $\mathrm{Al}-\mathrm{OH}^{2+}$ inner surface [28]. Cavallaro et al., investigated the structures of halloysite nanotubes (HNTs) from pristine by using small angle neutron scattering (SANS) [30]. Halloysite is a suitable mineral to be mixed with polymers and to obtain polymer-halloysite nanotubes which would act as adsorbents [33]. Halloysite can be easily modified to further increase its adsorptive efficiency $[29,31]$.

The aim of the present study, was to assess the capacity of modified halloysite clay to remove methyl orange dye from aqueous solutions. In this technique, the adsorption capacity of the clay was increased by modifying the halloysite itself. The adsorption capacities of the modified and unmodified clay were also compared. The characteristic properties of the prepared material was analyzed by using SEM, FTIR, XRD and DTA.

\section{Methods}

\subsection{Materials}

Halloysite clay was obtained from Biga, Soğucak village, Çanakkale Province, in Turkey. The studied halloysite mineral is formed by hydrothermal alteration of meteoric and/ or magmatic solutions of Lower Miocene volcanogenic units. The chemical composition and properties of the halloysite sample are shown in Table 1. Its cation-exchange capacity (CEC) is $5-10 \mathrm{meq} / 100 \mathrm{~g}$. The surfactant Cetyltrimethylammonium bromide (CTAB, 99\%, molecular weight $364.4 \mathrm{~g} \mathrm{~mol}^{-1}$ ) was purchased from Sigma Company. It features a chain with hydrophobic tail having 16 carbons and a quaternary trimethylammonium head group with $\mathrm{a}^{+1}$ charge (hydrophilic head). Methyl orange, sodium hydroxide and Hydrochloric acid were supplied from Merck and used as received. All other solvents were used without any further purification.

\subsection{Preparation of adsorbents}

The clay sample was first washed to remove dust and water soluble impurities and dried in an oven at $120^{\circ} \mathrm{C}$ until constant weight. The dried samples were grounded and sieved through 80 mesh sieve. The samples (unmodified halloysite) were then stored in a desiccator until later use as an adsorbent. However, for adsorption process it is important to modify halloysite by the addition either cationic or anionic surfactants [31, 32]. Cavallaro et al., investigated the effect of alkyl chain of the cationic surfactant on the halloysite nanotubes outer surface functionalization. For this purpose, they used $\mathrm{C} 10 \mathrm{Br}, \mathrm{C} 14 \mathrm{Br}$, and $\mathrm{C} 16 \mathrm{Br}$ as cationic surfactants and showed that the cationic surfactant is adsorbed at the outer surface due to electrostatic factors [31]. In this work $C T A B\left(\mathrm{C}_{16} \mathrm{H}_{33} \mathrm{~N}\left(\mathrm{CH}_{3}\right)_{3} \mathrm{Br}\right)$ as cationic surfactant, was used to modify the halloysite. The modified halloysite was prepared by dispersing the unmodified halloysite in a cetyltrimethylammonium bromide (CTAB) aqueous solution with a ratio of $10 \mathrm{~g} / 5.0 \mathrm{mmol}$ (halloysite/ CTAB), corresponding to $15.4 \%$ CTAB in weight. Weight percentage of the halloysite used in the modification
Table 1 The chemical analysis results of Soğucak halloysite sample

\begin{tabular}{lllllllllll}
\hline Component & $\mathrm{SiO}_{2}$ & $\mathrm{Al}_{2} \mathrm{O}_{3}$ & $\mathrm{Fe}_{2} \mathrm{O}_{3}$ & $\mathrm{MnO}$ & $\mathrm{CaO}$ & $\mathrm{MgO}$ & $\mathrm{Na}_{2} \mathrm{O}$ & $\mathrm{K}_{2} \mathrm{O}$ & LOI & Total \\
\hline Percentage & 41.30 & 35.10 & 0.49 & - & 0.02 & 0.69 & 0.25 & 0.10 & 22.25 & 100.20 \\
\hline
\end{tabular}


process is $84.6 \%$. Within the literature, similar halloysite/ CTAB ratios were used in the modification process. In a study conducted by Lu et al., $0.5 ; 1.0 ; 1.2 \mathrm{~g}$ CTAB were used with $10 \mathrm{~g}$ halloysite [34]. Cavallaro and coworkers $2 \mathrm{~g}$ of alkyltrimethylammonium bromide was used for the modification of $4 \mathrm{~g}$ halloysite [31]. In the studies performed by Liu et al., Halloysite/hexadecyltrimethyl ammonium bromide (HDTMA) ratio was used as $10 \mathrm{~g} / 7 \mathrm{mmol}$ [35]. In the present study, the preliminary experiments have shown that the optimum ratio for the $\mathrm{MO}$ adsorption process is $10 \mathrm{~g} / 1.8 \mathrm{~g}(10 \mathrm{~g} / 5 \mathrm{mmol})$ (Halloysite from Biga/CTAB) which coincides with literature studies. The dispersed unmodified halloysite/CTAB aqueous solution was continuously mixed for $5 \mathrm{~h}$ at constant temperature $\left(25^{\circ} \mathrm{C}\right)$. The concentrate solution was left for $1 \mathrm{~h}$ to settle down and then centrifugated to remove the solid part. The solid product (modified halloysite) was washed with distilled water until no Bromide ions were found from the filtrate by $0.1 \mathrm{M} \mathrm{AgNO}_{3}$ solution.

\subsection{Batch adsorption studies}

Methyl orange solutions were prepared by dissolving $\mathrm{MO}$ in distilled water with different concentrations; 20 ppm; 40 ppm; 60 ppm; 80 ppm. For the adsorption studies, $0.5 \mathrm{~g}$ of adsorbents were placed in conical flasks containing $50 \mathrm{~mL}$ of dye solutions. The $\mathrm{pH}$ of the solutions was adjusted to 6.5 by adding dilute hydrochloric acid or sodium hydroxide solutions. Right at the beginning of the adsorption process, the flasks with different concentrations were immediately sealed with parafilm and placed in waterbath at constant temperature. During the adsorption process, the concentration of $\mathrm{MO}$ was gauged using Double Beam UV Visible Spectrophotometer, (T-80, PG Instruments) at the maximum wavelength $\left(\lambda_{\max }=464 \mathrm{~nm}\right)$.

\subsection{Equilibrium studies}

The MO adsorption capacities of modified and unmodified halloysite as an adsorbent were investigated by batch adsorption experiments. The uptake percent values of $\mathrm{MO}$ were estimated using Eq. 1.

$\%$ Uptake $=\frac{C_{o}-C_{t}}{C_{o}} \times 100$

where $C_{o}(p p m)$ is the initial concentration of dye and $C_{t}$ indicates the concentration of dye (ppm) in the solution at time t. $C_{t}$ values turn to $C_{e}$ at equilibrium. The amount of dye adsorbed per unit mass of the adsorbents was estimated by the following equation.
$q_{t}=\frac{C_{o}-C_{t}}{W} \times V$

In this equation, $\mathrm{q}_{\mathrm{t}}\left(\mathrm{mg} \mathrm{g}^{-1}\right)$ is the adsorbed amount of dye by the certain amount of solid adsorbent at time $t$. At equilibrium $q_{t}$ values turn to $q_{e}\left(\mathrm{mg} \mathrm{g}^{-1}\right)$ values which is known as the equilibrium adsorption capacity. $\mathrm{V}(\mathrm{L})$ is the volume of the dye solution and $w(g)$ is the mass of the adsorbent.

\section{Results and discussion}

\subsection{Characterization of unmodified and modified halloysite}

Halloysite clay mineral used in this work, is the most important member of the kaoline group. Halloysite has the formula $\mathrm{Al}_{2} \mathrm{Si}_{2} \mathrm{O}_{5}(\mathrm{OH})_{4} \cdot 2 \mathrm{H}_{2} \mathrm{O}$ and it occurs typically in a tubular morphology. It is similar to the kaolinite structure, but kaolinite occurs in platy forms and its formula is $\mathrm{Al}_{2} \mathrm{Si}_{2} \mathrm{O}_{5}(\mathrm{OH})_{4}$ [36]. Therefore, a single layer of water molecules is sandwiched between two layers of halloysites. Halloysite is becoming increasingly important mainly due to its use in nanotechnology applications which takes advantage of its tubular structure [37]. In order to reveal the mineralogical changes and differences that will occur as a result of modification, $\mathrm{X}$-ray diffraction method was used and the changes between the crystallinities of both natural (unmodified) and modified halloysite were compared. XRD patterns of unmodified and modified halloysite samples presented in Fig. 1 were obtained using the Philips PW1730 X-ray Diffraction System. After the modification process, the peak intensities of halloysite decreased and some peaks shifted. The crystallinity of the halloysite decreased and the $\mathrm{d}$ values corresponding to the $2 \theta$ angles changed with the effect of the modification. The peaks observed at $4.42 \AA$ and $3.35 \AA$ in natural halloysite, shifted to $4.39 \AA$ and $3.57 \AA$, respectively. Instead of the sharp peaks indicating alumina crystals, modified halloysite showed a broad band. XRD analysis results of unmodified halloysite (Fig. 1a) and modified halloysite (Fig. 1b) showed that the distance between layers in modified halloysite increased compared to unmodified halloysite. These results coincide with the results of Lim and coworkers studied on the modification of halloysite nanotubes for enhancement of its adsorption capacity [38]. The shifting of the peaks and decreasing intensities in the modified halloysite demonstrated that the modification process was successful.

DTA measurements were conducted in $\mathrm{N}_{2}$ atmosphere using Shimadzu DTA-50 Differential Thermal Analyzer. The temperatures range from 0 to $1000{ }^{\circ} \mathrm{C}$ at a heating 


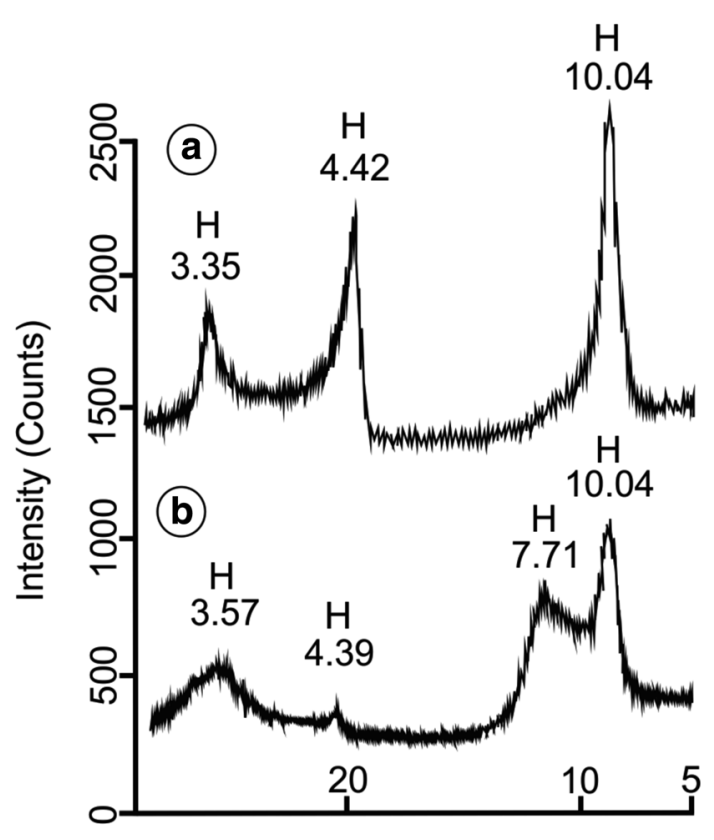

$\left({ }^{\circ} 2 \theta \mathrm{Cu} \mathrm{K \alpha}\right)$

Fig. 1 XRD pattern of (a) unmodified halloysite (b) modified halloysite

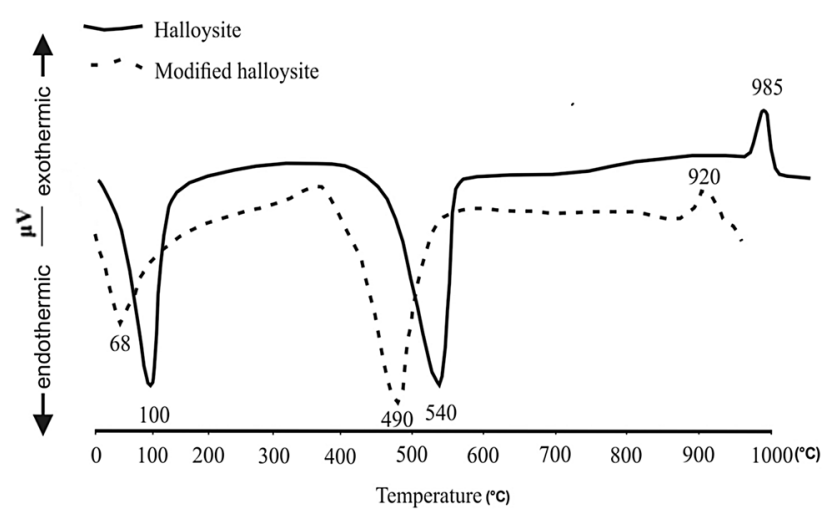

Fig. 2 DTA graphs of unmodified and modified halloysite measured in nitrogen at a flow rate of $130 \mathrm{~mL} \mathrm{\textrm {min } ^ { - 1 }}$

rate of $20^{\circ} \mathrm{C} \mathrm{min}^{-1}$. Figure 2 indicates DTA analysis of halloysite mineral with one exothermic peak at $985^{\circ} \mathrm{C}$ and two endothermic peaks at $100-540{ }^{\circ} \mathrm{C}$. During the heating process in DTA measurement, the interlayer water in halloysite clay is readily and irreversibly lost which is called endothermic effect. The peak observed at $100^{\circ} \mathrm{C}$ attributed to this releasing of water between the layers in halloysite. Due to the lost of water the distances between the layers of clay are closer and the size of halloysite $\left[\mathrm{Al}_{2} \mathrm{Si}_{2} \mathrm{O}_{5}(\mathrm{OH})_{4} \cdot 2 \mathrm{H}_{2} \mathrm{O}\right.$ ] layers reduces from 10 to $7 \AA$. The second endothermic peak at $540^{\circ} \mathrm{C}$ as the result of the dehydroxylation of the structure. The exothermic peak at $985{ }^{\circ} \mathrm{C}$ indicates the formation of the mullite phase. These results are in agreement with literature [39, 40]. The endothermic and exothermic peaks in modified halloysite were observed at lower temperatures, with faster loss of water between the layers (Fig. 2).

The FTIR graph of the modified and unmodified samples were recorded with the wavenumber ranging from 400 to $4000 \mathrm{~cm}^{-1}$ by the ThermoNicolet $380 \mathrm{FT}$ model device (Fig. 3).

As seen from the spectrum of the halloysite in Fig. 3, the absorption peaks at 3695 and $3617 \mathrm{~cm}^{-1}$ are attributed to the stretching vibrations of $\mathrm{Al}-\mathrm{OH}$ bonds. The absorption peaks at 1032 and $910 \mathrm{~cm}^{-1}$ represented the $\mathrm{Al}-\mathrm{OH}$ bending vibration. The peak at $690 \mathrm{~cm}^{-1}$ referred to the $\mathrm{Si}-\mathrm{O}$ stretching vibration peak. The dehydroxylation of halloysite takes place in steps with the first hydroxyl loss taking place homogenously and the second inhomogenously as reported by Frost and Vassalo [41]. The wide peak observed in unmodified halloysite at $3472 \mathrm{~cm}^{-1}$ has disappeared in the modified halloysite. This result indicates that the outer hydroxyls of halloysite have disappeared. Similarly, the decrease in peak intensity at $3617 \mathrm{~cm}^{-1}$ in halloysite and two new peaks observed at 3737 and $3635 \mathrm{~cm}^{-1}$ in modified halloysite shows the decrease of inner hydroxyl groups in halloysite. Table 2 reports the FTIR spectral data obtained by the FTIR absorption spectra of halloysite. Similar results are observed in Frost and Vassalo work [41].

Morphological analysis of Halloysite clay was observed by using, JEOL 6510-LV JSM SEM instrument (Fig. 4a, b).

As seen from Fig. 4a, halloysite is in a tubular state with the size between $5 \mu \mathrm{m}$ and $200 \mathrm{~nm}$ in length. Figure $4 \mathrm{~b}$ represents the morphology of halloysite after modification process. It can be observed clearly that the length of halloysite rods shortened due to modification. The irregular structure of the tubular shape of halloysite should be convenient for the adsorption of MO dye with high capacity. Comparing Fig. $4 \mathrm{a}$, $\mathrm{b}$ it can be observed that the length of the unmodified Halloysite rods is higher than $1 \mu \mathrm{m}$ whereas the length of the modified halloysite rods is less than $1 \mu \mathrm{m}$ as pointed in Fig. 4. Similar study was seen in Pasbakhsh et al. work [42]. They measured the length of Halloysite rods is about $1 \mu \mathrm{m}$ while the external diameters range between 20 and $200 \mathrm{~nm}$.

\subsection{Effect of initial MO concentration and contact time on adsorption}

The adsorption of dye by the unmodified and modified Halloysite was examined at different initial methyl orange concentrations (20 ppm; 40 ppm; 60 ppm; 80 ppm). Thus, during the adsorption experiments, the color difference between the dye solutions prepared at these 


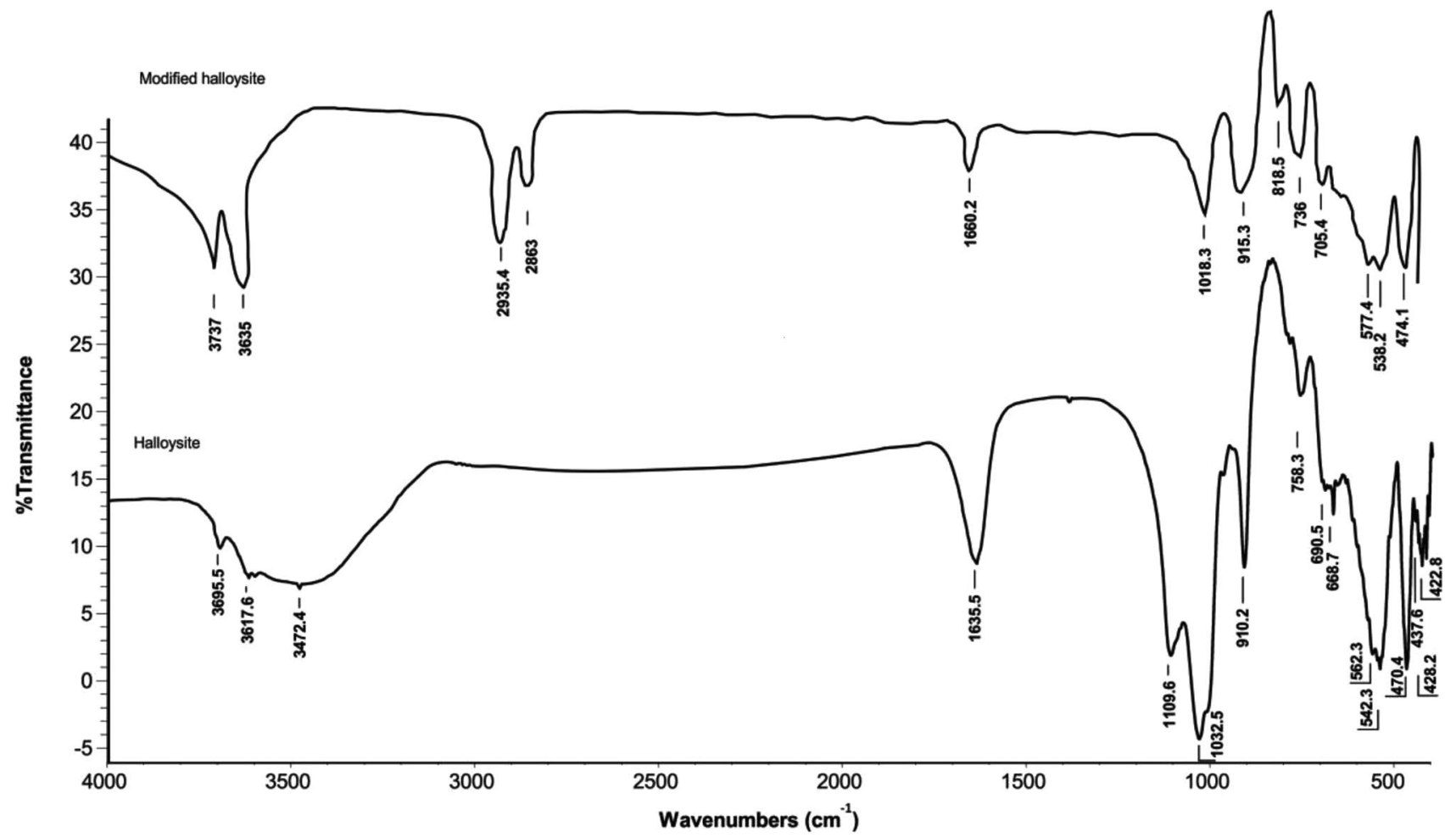

Fig. 3 FTIR graph of the modified (above) and unmodified halloysite (below)

Table 2 FTIR data for halloysite sample

\begin{tabular}{ll}
\hline FTIR absorption $\left(\mathrm{cm}^{-1}\right)$ & Probable assignment \\
\hline 437 & SiO bending \\
470 & SiO bending \\
542 & Si-O-Al deformation \\
690 & Si-O stretching \\
758 & OH translation \\
910 & AlOH bending vibration \\
1032 & AlOH bending vibration \\
3695 & Al-OH stretching vibration
\end{tabular}

concentrations is also noticeable visually, and it was possible to follow the adsorption visually as well as absorbance measurements in UV spectrophotometer.

The amount of the adsorption increased with the increasing of the initial dye concentration. The uptake percentage of $\mathrm{MO}$ adsorbed on unmodified halloysite increases from $38 \%$ to $46 \%$ as the concentration changes from 20 to $80 \mathrm{ppm}$ whereas the uptake value increases from $65 \%$ to $91 \%$ for the modified halloysite as seen in Figs. 5 and 6 , respectively. This situation may be explained the increasing of the driving force of the concentration gradient due to the increasing of the initial concentration
Fig. 4 SEM images of (a) unmodified halloysite, (b) modified halloysite
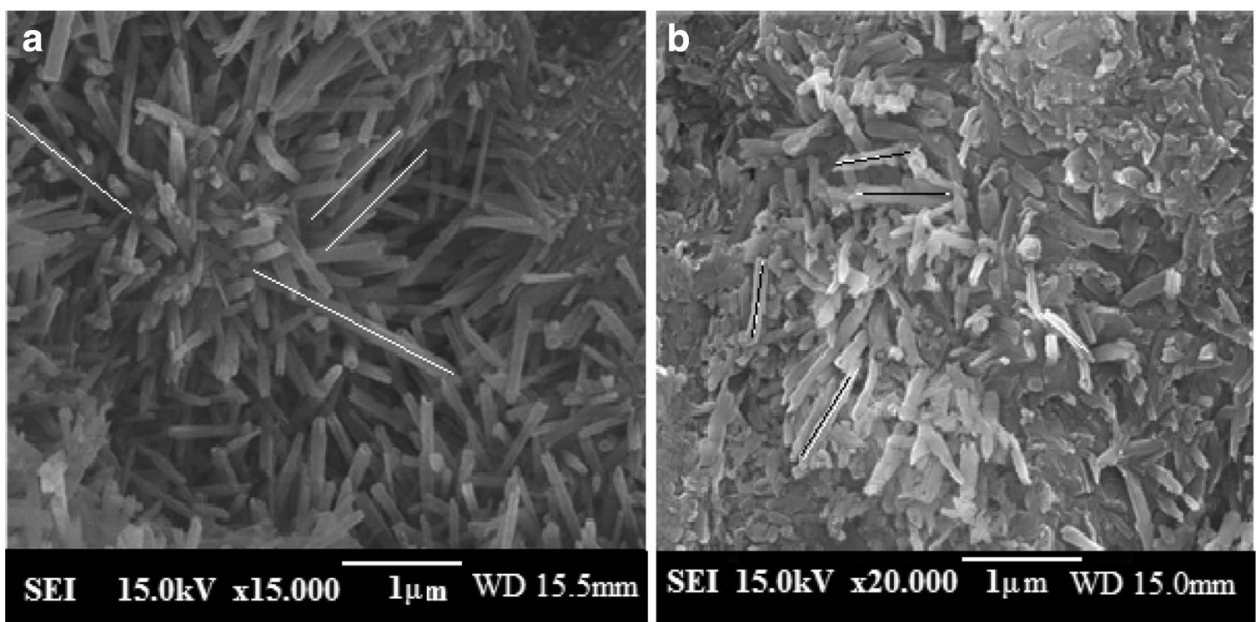


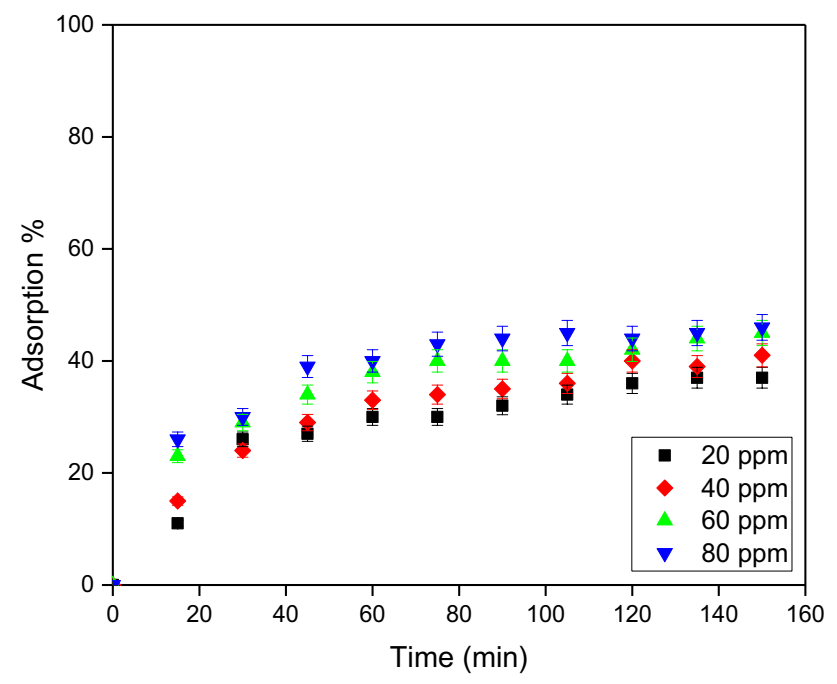

Fig. 5 The effect of initial concentration on the adsorption (\%) of MO on unmodified Halloysite, at $25^{\circ} \mathrm{C}$

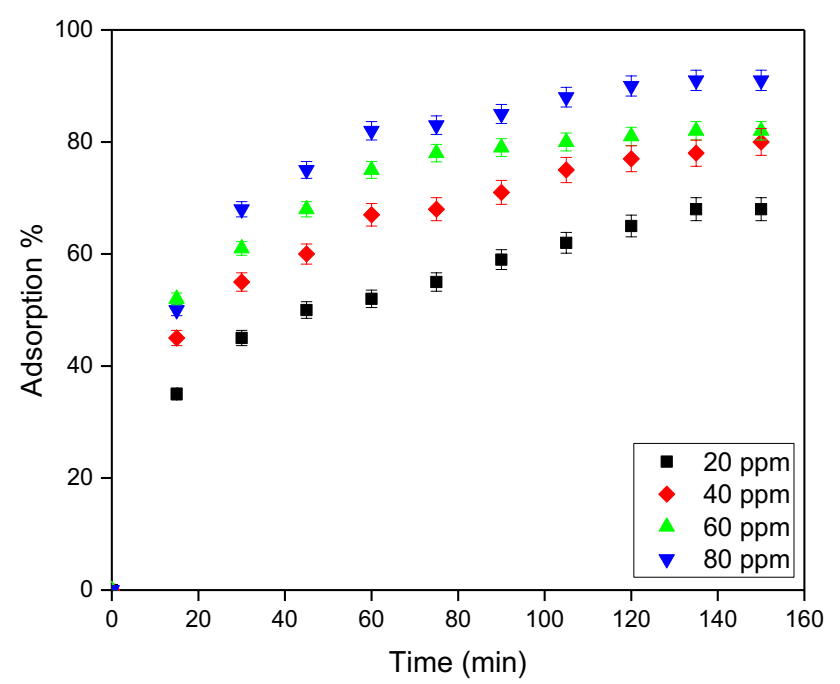

Fig. 6 The effect of initial concentration on the adsorption (\%) of MO on modified halloysite, at $25^{\circ} \mathrm{C}$

of $\mathrm{MO}$ to overcome the mass transfer resistance of methyl orange between the solid and liquid phase [35]. The amount of adsorbed MO on both adsorbents at high initial dye concentrations achieved adsorption equilibrium in about $95 \mathrm{~min}$.

\subsection{Kinetic modeling}

\subsubsection{Pseudo first-order kinetic model}

The adsorption kinetics of MO were carried out by the well-known (Lagergren's pseudo first-order and pseudo second-order models $[43,44]$.
Pseudo first-order kinetic model is expressed as the following equation.

$\mathrm{dq}_{\mathrm{t}} / \mathrm{dt}=\mathrm{k}_{1}\left(\mathrm{q}_{\mathrm{e}}-\mathrm{q}_{\mathrm{t}}\right)$

Integrating of Eq. 3. for the boundary conditions, at $\mathrm{t}=0, \mathrm{q}_{\mathrm{t}}=0$ and $\mathrm{t}=\mathrm{t}, \mathrm{q}_{\mathrm{t}}=\mathrm{q}_{\mathrm{t}}$ gives the Eq. 4 .

$\ln \left[\left(\mathrm{q}_{\mathrm{e}}-\mathrm{q}_{\mathrm{t}}\right) / \mathrm{q}_{\mathrm{e}}\right]=-\mathrm{k}_{1} \mathrm{t}$

where, $k_{1}$ is the pseudo first-order rate constant of the adsorption $\left(\mathrm{min}^{-1}\right)$. The values of $\mathrm{k}_{1}$ and $\mathrm{q}_{\mathrm{e}}$ can be estimated from the slope and intercept of the plot drawn between $\ln \left(q_{e}-q_{t}\right)$ and $t$, respectively.

\subsubsection{Pseudo second-order model}

The pseudo second-order kinetic model is analyzed by Ho and McKay based on the adsorption capacity and is expressed as follows [44];

$\mathrm{t} / \mathrm{q}_{\mathrm{t}}=1 / \mathrm{h}+\mathrm{t} / \mathrm{q}_{\mathrm{e}}$

$h=k_{2} q^{2}$

where, $\mathrm{h}\left(\mathrm{mg} \mathrm{g}^{-1} \mathrm{~min}^{-1}\right)$ is the initial adsorption rate, $\mathrm{k}_{2}$ $\left(\mathrm{g} \mathrm{mg}^{-1} \mathrm{~min}^{-1}\right)$ is the equilibrium rate constant of pseudosecond order model. The values of $\mathrm{q}_{\mathrm{e}}$ and $\mathrm{k}_{2}$ were calculated from the slope and intercept of the graph drawn between $t / q_{t}$ and $t$, respectively.

Comparing the adsorption capacities and the correlation coefficient squared values, $R^{2}$ showed that the experimental data obtained from modified and unmodified halloysites do not fit with pseudo first order kinetic model. Figure 7 represents the pseudo first-order kinetic model for the $\mathrm{MO}$ adsorption in different initial concentrations on modified halloysite, at $25^{\circ} \mathrm{C}$.

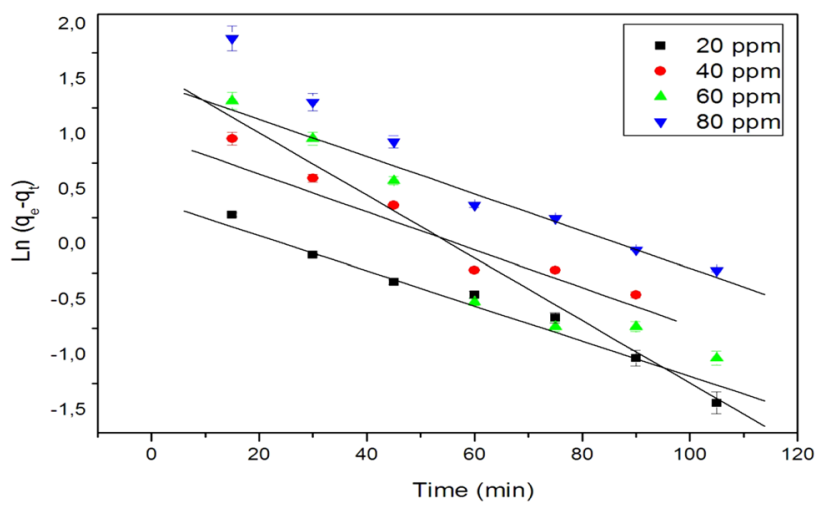

Fig. 7 The pseudo first-order kinetic model for the MO adsorption in different initial concentrations on modified halloysite, at $25^{\circ} \mathrm{C}$ 


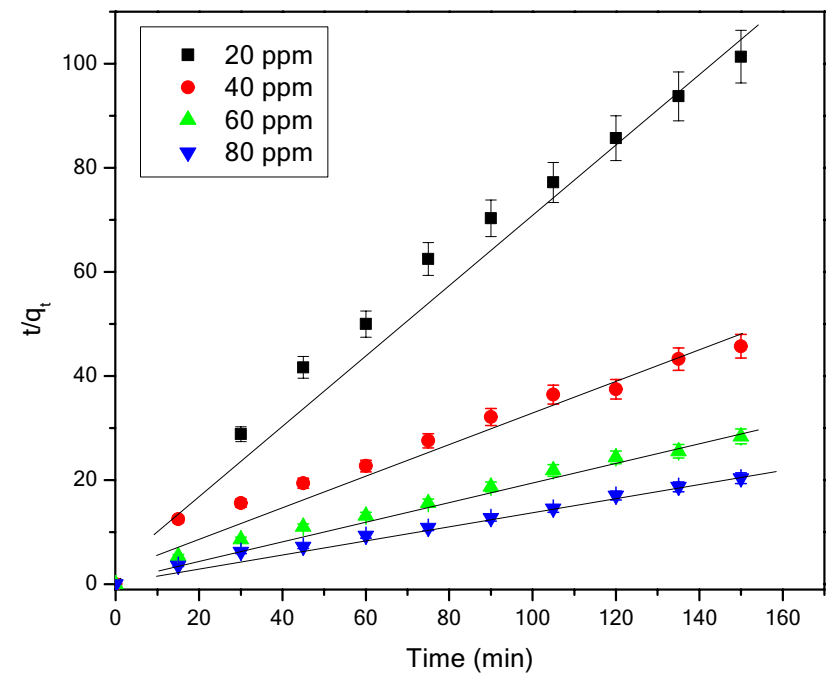

Fig. 8 The pseudo second-order kinetic model for the MO adsorption in different initial concentrations on unmodified halloysite, at $25^{\circ} \mathrm{C}$

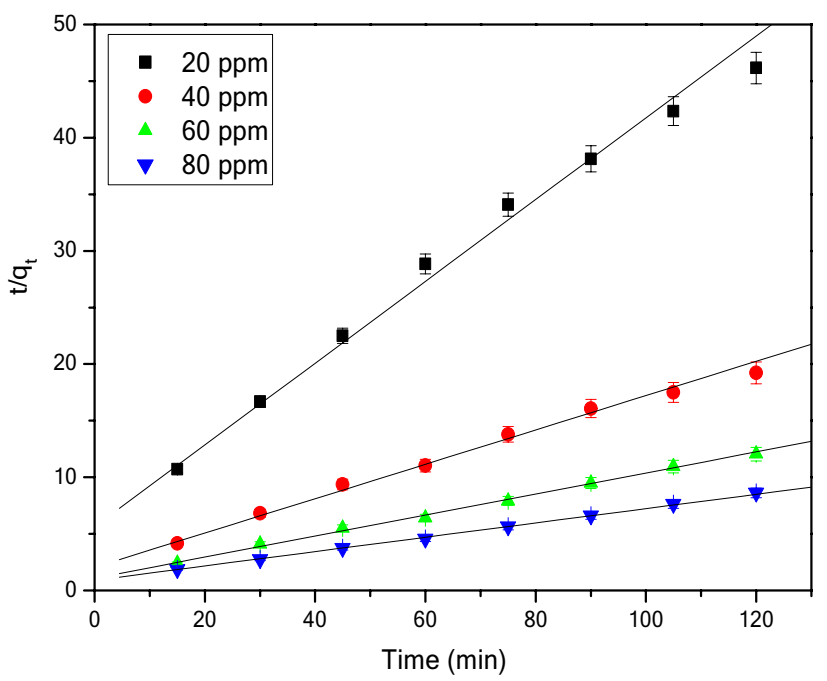

Fig. 9 The pseudo second-order kinetic model for the MO adsorption in different initial concentrations on modified halloysite, at $25^{\circ} \mathrm{C}$

By studying the kinetics of the unmodified and modified halloysite, it was found that their adsorption kinetics fit the second order kinetic model. Kinetic analysis of the $\mathrm{MO}$ adsorption on unmodified and modified halloysite reveals $\mathrm{R}^{2}$ values greater than 0.98 and 0.99 which is best fit for a second degree kinetic model (Figs. 8 and 9 ).

The kinetic parameters for the unmodified and modified halloysite were listed in Tables 3 and 4, respectively.

The calculated $\mathrm{q}_{\mathrm{e}}$, values $\left(\mathrm{q}_{\mathrm{e}, \mathrm{cal}}\right)$ are compared to the experimental $q_{e}$ values $\left(q_{e, e x p}\right)$ in the case of pseudo firstorder and pseudo second-order kinetic model. These comparative results and the $R^{2}$ values obtained from the graphs give the information about the suitability of the second order kinetic model for the adsorption process. The experimental values $\left(q_{e, e x p}\right)$ for the adsorbents do not comply with the calculated values, $\left(\mathrm{q}_{\mathrm{e}, \mathrm{cal}}\right)$ for the Lagergren's pseudo first-order equation. On the other hand, the calculated $\mathrm{q}_{\mathrm{e}}$ values, agree with the experimental values and the correlation coefficients are very high in the case of pseudo second-order kinetic equation for the unmodified and modified halloysite. These results indicate the applicability of the second-order model for the adsorption of $\mathrm{MO}$ on both adsorbents. $\mathrm{qe}_{\exp }$ and qe $\mathrm{e}_{\text {calc }}$ values for the unmodified halloysite are also very close. However, comparative analysis of adsorption capacities shows much greater values for the modified halloysite for all the concentrations of $\mathrm{MO}$.

\subsubsection{Intra-particle diffusion}

To identify the diffusion mechanism of the adsorption process, the kinetic data were then analyzed using the intraparticle model. According to this model the mechanism of the dye adsorption are proposed by several stages. The first stage is the migration of dye molecules from the solution phase to the exterior surface of the adsorbent (bulk diffusion) and spreads onto its surface. In the second stage, the dye molecules diffuse through the boundary layer which is called film diffusion. The next stage is called as pore diffusion and the dye molecules move into interior of the pores. The intra-particle diffusion model is proposed by Weber and Morris and is calculated using the following equation [45].

$\mathrm{q}_{\mathrm{t}}=\mathrm{k}_{\mathrm{id}} \mathrm{t}^{1 / 2}+\mathrm{C}$

where, $\mathrm{k}_{\mathrm{id}}\left(\mathrm{mg} \mathrm{g}^{-1} \mathrm{~min}^{-1 / 2}\right)$ is the rate constant of the intraparticle diffusion obtained from the slope, $C\left(\mathrm{mg} \mathrm{g}^{-1}\right)$ is constant found from the intercept of the plot drawn between $q_{t}$ and $t^{1 / 2}$. $C$ value gives information about the thickness of the boundary layer. Based on this model, the intra-particle diffusion is the sole rate-limiting step when the plot passes through the origin (as C equals to zero) [45].

Two linear parts are observed on the graph in Fig. 10 and the plots pass from the origin. This result shows that intra-particle diffusion is the rate-controlling step. The first part represents the boundary layer effect. The second part relates to the pore diffusion. The diffusion rate constants, $\mathrm{k}_{\mathrm{p} 1}, \mathrm{k}_{\mathrm{p} 2}$, were calculated from the slope of the first and the second linear parts.

According to Fig. 10 and the $\mathrm{R}^{2}$ values in Table 3, the adsorption mechanism of $\mathrm{MO}$ on the modified halloysite follows the intra-particle diffusion model which confirms that the adsorption of MO on the modified halloysite involves both the adsorption on the surface of the 
Table 3 The kinetic parameters for the adsorption of $\mathrm{MO}$ by Unmodified Halloysite at $25^{\circ} \mathrm{C}$
Table 4 The kinetic parameters for the adsorption of $\mathrm{MO}$ by Modified Halloysite at $25^{\circ} \mathrm{C}$

\begin{tabular}{lllll}
\hline Pseudo first-order & \multicolumn{3}{l}{} \\
\hline Concentration $(\mathrm{ppm})$ & $\mathrm{k}_{1}\left(\mathrm{~min}^{-1}\right)$ & $\mathrm{q}_{\mathrm{e} . \text { exp }}\left(\mathrm{mg} \mathrm{g}^{-1}\right)$ & $\mathrm{q}_{\text {e.cal }}\left(\mathrm{mg} \mathrm{g}^{-1}\right)$ & $\mathrm{R}^{2}$ \\
\hline 20 & 0.0230 & 1.44 & 1.22 & 0.949 \\
40 & 0.0228 & 3.12 & 2.35 & 0.973 \\
60 & 0.0186 & 5.28 & 2.98 & 0.912 \\
80 & 0.0399 & 7.2 & 6.59 & 0.972 \\
Pseudo second-order & & & & \\
Concentration (ppm) & $\mathrm{k}_{2}\left(\mathrm{~g} \mathrm{mg}^{-1} \mathrm{~min}^{-1}\right)$ & $\mathrm{q}_{\mathrm{e} . \mathrm{exp}}\left(\mathrm{mg} \mathrm{g}^{-1}\right)$ & $\mathrm{q}_{\mathrm{e} . \mathrm{cal}}\left(\mathrm{mg} \mathrm{g}^{-1}\right)$ & $\mathrm{R}^{2}$ \\
20 & 0.0490 & 1.44 & 1.54 & 0.982 \\
40 & 0.0137 & 3.12 & 3.58 & 0.973 \\
60 & 0.0248 & 5.28 & 5.55 & 0.989 \\
80 & 0.0128 & 7.2 & 7.75 & 0.992 \\
\hline
\end{tabular}

\begin{tabular}{lllll}
\hline Pseudo first-order & \multicolumn{5}{l}{} \\
\hline Concentration (ppm) & $\mathrm{k}_{1}\left(\mathrm{~min}^{-1}\right)$ & $\mathrm{q}_{\text {e.exp }}\left(\mathrm{mg} \mathrm{g}^{-1}\right)$ & $\mathrm{q}_{\mathrm{e} . \text { cal }}\left(\mathrm{mg} \mathrm{g}^{-1}\right)$ & $\mathrm{R}^{2}$ \\
\hline 20 & 0.0174 & 2.72 & 1.68 & 0.974 \\
40 & 0.0236 & 6.24 & 3.90 & 0.929 \\
60 & 0.0279 & 9.96 & 5.25 & 0.912 \\
80 & 0.0231 & 14.56 & 7.56 & 0.956 \\
Pseudo second-order & & & & \\
Concentration (ppm) & $\mathrm{k}_{2}\left(\mathrm{~g} \mathrm{mg}^{-1} \mathrm{~min}^{-1}\right)$ & $\mathrm{q}_{\mathrm{e} . \text { exp }}\left(\mathrm{mg} \mathrm{g}^{-1}\right)$ & $\mathrm{q}_{\mathrm{e} . \mathrm{cal}}\left(\mathrm{mg} \mathrm{g}^{-1}\right)$ & $\mathrm{R}^{2}$ \\
20 & 0.0166 & 2.72 & 2.94 & 0.991 \\
40 & 0.0083 & 6.24 & 6.93 & 0.993 \\
60 & 0.0071 & 9.96 & 10.90 & 0.997 \\
80 & 0.0050 & 14.56 & 15.51 & 0.999 \\
Intraparticle diffusion & & & & \\
Concentration (ppm) & $\mathrm{k}_{\mathrm{p} 1}\left(\mathrm{mg} \mathrm{g}^{-1} \mathrm{~min}^{-1 / 2}\right)$ & $\mathrm{R}^{2}$ & $\mathrm{k}_{\mathrm{p} 2}\left(\mathrm{mg} \mathrm{g}^{-1} \mathrm{~min}^{-1 / 2}\right)$ & $\mathrm{R}^{2}$ \\
20 & 0.2768 & 0.960 & 0.1734 & 0.999 \\
40 & 0.6965 & 0.967 & 0.3049 & 0.936 \\
60 & 1.1872 & 0.966 & 1.1879 & 0.902 \\
80 & 1.7241 & 0.979 & 0.3864 & 0.905 \\
\hline
\end{tabular}

adsorbent and the diffusion into the interior of the pores of the adsorbent.

\subsection{Adsorption isotherms}

The adsorption isotherm models give the important information about the distribution of the adsorbate molecules between solid and liquid phase at equilibrium state. The adsorption of $\mathrm{MO}$ onto the modified halloysite was studied with the commonly used isotherm models as Langmuir, Freundlich, D-R and Sips.

\subsubsection{Langmuir isotherm}

The linear form of the Langmuir equation is expressed as [46];

\section{SN Applied Sciences}

$\frac{1}{q_{e}}=\frac{1}{q_{m}}+\frac{1}{\left(q_{m} K_{L}\right) C_{e}}$

where $C_{e}(p p m)$ is the equilibrium concentration of $M O$ in solution and $\mathrm{q}_{\mathrm{e}}\left(\mathrm{mg} \mathrm{g}^{-1}\right)$ is the amount of $\mathrm{MO}$ adsorbed per unit weight of the adsorbents. $\mathrm{K}_{\mathrm{L}}\left(\mathrm{L} \mathrm{mg}^{-1}\right)$ is the Langmuir constant related to the affinity and the energy of adsorption. $Q_{m}$ is the maximum adsorption capacity with complete monolayer coverage on the adsorbent surface $\left(\mathrm{mg} \mathrm{g}^{-1}\right)$. Langmuir isotherm can be discussed in terms of the dimensionless constant, $R_{L}$ which is calculated by using the following equation.

$\mathrm{R}_{\mathrm{L}}=1 /\left(1+\mathrm{q}_{\mathrm{m}} \mathrm{K}_{\mathrm{L}}\right)$

According to the value of the separation factor, $R_{L}$ of Langmuir model, the adsorption process can be expressed 


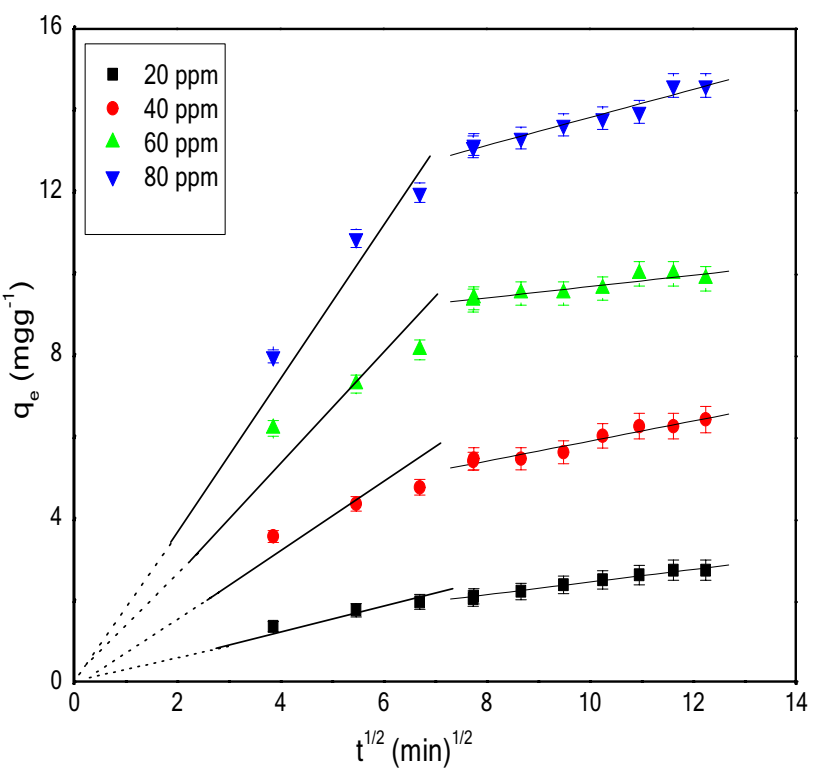

Fig. 10 Intraparticle diffusion kinetics of MO onto Modified Halloysite at $25^{\circ} \mathrm{C}$

as; favourable $\left(0<R_{L}<1\right)$, unfavourable $\left(R_{L}>1\right)$, linear $\left(R_{L}=1\right)$ and irreversible $\left(R_{L}=0\right)$. From the experimental results and Fig. 11, the value of $R_{L}$ was estimated as 0.799 which is between 0.0 and 1.0. This result represents the favorable adsorption of $\mathrm{MO}$ on modified Halloysite under experimental conditions. The value of $\mathrm{q}_{\mathrm{m}}$ was found from the intercept $\left(3.58 \mathrm{mg} \mathrm{g}^{-1}\right)$ whereas $\mathrm{K}_{\mathrm{L}}$ value $\left(0.07 \mathrm{~L} \mathrm{mg}^{-1}\right)$ was estimated from the slope of the graph in Fig. 11. Simi$\operatorname{lar} \mathrm{K}_{\mathrm{L}}$ and $\mathrm{q}_{\mathrm{m}}$ values were obtained by Robati and co-workers for the adsorption of methyl orange using graphene oxide as an adsorbent [47].

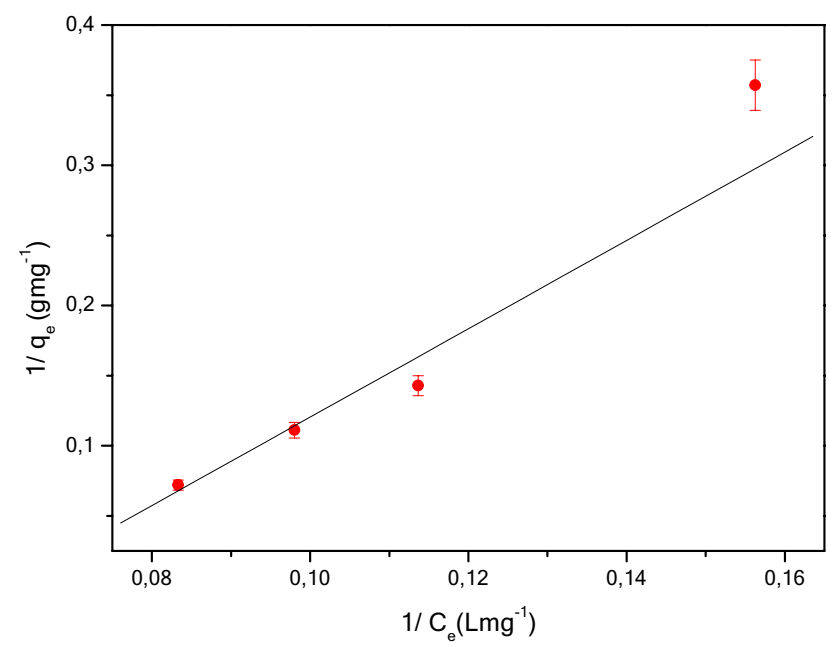

Fig. 11 Langmuir Isotherm, at $25^{\circ} \mathrm{C}$

\subsubsection{Freundlich isotherm}

Freundlich isotherm based on the heterogenous surface is given by the following equation

$\mathrm{q}_{\mathrm{e}}=\mathrm{K}_{\mathrm{F}} \mathrm{C}^{1 / \mathrm{n}}$

where, $\mathrm{K}_{\mathrm{F}}$ and $\mathrm{n}$ are Freundlich constants related to adsorption capacity and adsorption intensity, respectively. The linear form of Freundlich isotherm is expressed as [48];

$\log \mathrm{q}_{\mathrm{e}}=\log \mathrm{K}_{\mathrm{F}}+1 / \mathrm{n} \log \mathrm{C}_{\mathrm{e}}$

Freundlich isotherm constants of $\mathrm{K}_{\mathrm{F}}\left(\mathrm{mg} \mathrm{g}^{-1} \mathrm{mg}^{-1 / n}\right)$ and $1 / \mathrm{n}$ are determined from the intercept and the slope of the linear plot of $\log C_{e}$ versus $\log q_{e^{\prime}}$ respectively. Figure 12 indicated the linear correlation.

Comparing $R^{2}$ values from the Freundlich model $\left(R^{2}=0.993\right)$ and the Langmuir model $\left(R^{2}=0.969\right)$ it was seen that the data obtained from adsorption fit both isotherms. It has been observed that there is a heterogeneous adsorption after monolayer adsorption. It also confirmed the heterogeneous nature of the surface of the modified halloysite.

\subsubsection{Dubinin-Radushkevich (D-R) isotherm}

The Dubinin-Radushkevich (D-R) model, an empirical isotherm, used to discuss the effect of the porous structure of the adsorbent is developed according to Polanyi's theory. Based on this theory it is assumed that the distribution of pores in adsorbent follows the Gaussian energy distribution [49]. The linear form of D-R model is presented as [50],

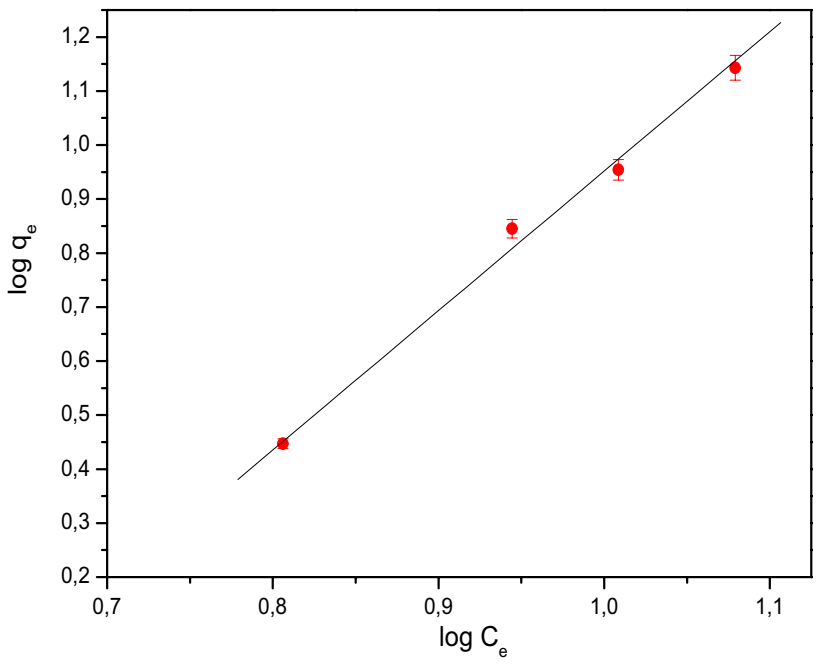

Fig. 12 Freundlich Isotherm, at $25^{\circ} \mathrm{C}$ 
$\ln \mathrm{qe}=\ln \mathrm{q}_{\mathrm{D}-\mathrm{R}}-\mathrm{K}_{\mathrm{D}-\mathrm{R}} \varepsilon^{2}$

where, $\mathrm{q}_{\mathrm{D}-\mathrm{R}}\left(\mathrm{mg} \mathrm{g}^{-1}\right)$ is a constant in D-R isotherm model which relates to adsorption capacity. $\mathrm{K}_{\mathrm{D}-\mathrm{R}}\left(\mathrm{mol}^{2} \mathrm{~J}^{-2}\right)$ is the Dubinin-Radushkevich isotherm constant due to the adsorption mean free energy. $\varepsilon\left(\mathrm{kJ} \mathrm{mol}^{-1}\right)$ is the Polanyi adsorption potential in terms of $C_{e}$.

$\varepsilon=\mathrm{R} \operatorname{Tn}\left(1+1 / C_{\mathrm{e}}\right)$

Here, $R$ is gas constant and $T$ is the temperature $(K)$. The slope of the plot of $\operatorname{Inq}_{e}$ versus $\varepsilon^{2}$ in Eq. 12 gives $K_{D-R}$ and the intercept yields the adsorption capacity. The values of $\mathrm{K}_{\mathrm{D}-\mathrm{R}}$ and $\mathrm{q}_{\mathrm{D}-\mathrm{R}}$ are listed in Table 5 with their corresponding value of the correlation coefficient, $R^{2}$. The apparent energy $(E, \mathrm{~kJ} / \mathrm{mol})$ of the adsorption from $D-R$ isotherm model can be estimated using the following equation.

$E=1 / \sqrt{ } 2 K_{D-R}$

$E$ is usually computed to determine whether the adsorption is dominated by physical $\left(E<8 \mathrm{~kJ} \mathrm{~mol}^{-1}\right)$ or chemical process $\left(8<\mathrm{E}<16 \mathrm{~kJ} \mathrm{~mol}^{-1}\right)$. Hu and Zhang discussed this model thoroughly and they showed that there were some discrepancies in the D-R model applied [51].

As seen in Fig. 13 the D-R isotherm model can also fit the adsorption by modified halloysite well and the activation energy (E) was estimated from this model as $0.1 \mathrm{~kJ} \mathrm{~mol}^{-1}$. Therefore, the adsorption of MO on modified halloysite can be considered as physical adsorption and

Table 5 The isotherm constants calculated for different adsorption isotherm models

\begin{tabular}{lll}
\hline Isotherm models & Parameters & Values \\
\hline Langmuir & & \\
& $\mathrm{q}_{\max }\left(\mathrm{mg} \mathrm{g}^{-1}\right)$ & 3.58 \\
& $\mathrm{~K}_{\mathrm{L}}\left(\mathrm{L} \mathrm{mg}^{-1}\right)$ & 0.07 \\
& $\mathrm{R}^{2}$ & 0.969 \\
Freundlich & & \\
& $\mathrm{K}_{\mathrm{F}}\left(\mathrm{mg} \mathrm{g}^{-1}\right)$ & 0.208 \\
& $\mathrm{n}$ & 0.397 \\
& $\mathrm{R}^{2}$ & 0.993 \\
D-R & & \\
& $\mathrm{K}_{\mathrm{D}-\mathrm{R}}\left(\mathrm{mol}^{2} \mathrm{~J}^{-2}\right)$ & $5 \times 10^{-5}$ \\
& $\mathrm{q}_{\mathrm{D}-\mathrm{R}}\left(\mathrm{mg} \mathrm{g}^{-1}\right)$ & 6.636 \\
& $\mathrm{R}^{2}$ & 0.903 \\
& & \\
Sips & $\mathrm{q}_{\mathrm{m}}\left(\mathrm{mg} \mathrm{g}^{-1}\right)$ & 39.2 \\
& $\mathrm{~K}_{\mathrm{S}}\left(\mathrm{L} \mathrm{mg}^{-1}\right)$ & $1.07 \times 10^{-3}$ \\
& $\mathrm{n}$ & 0.997 \\
& $\mathrm{R}^{2}$ & \\
& &
\end{tabular}

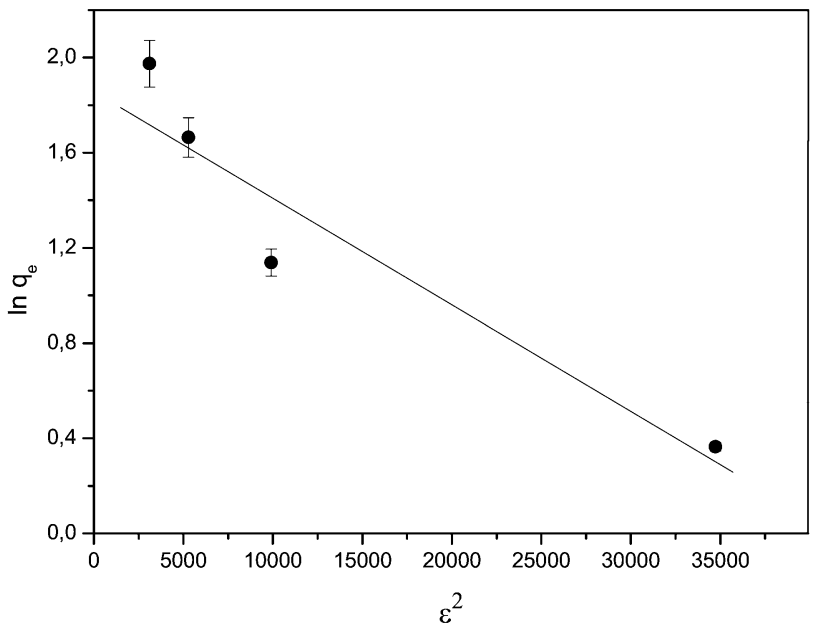

Fig. 13 Dubinin-Radushkewich Isotherm, at $25^{\circ} \mathrm{C}$

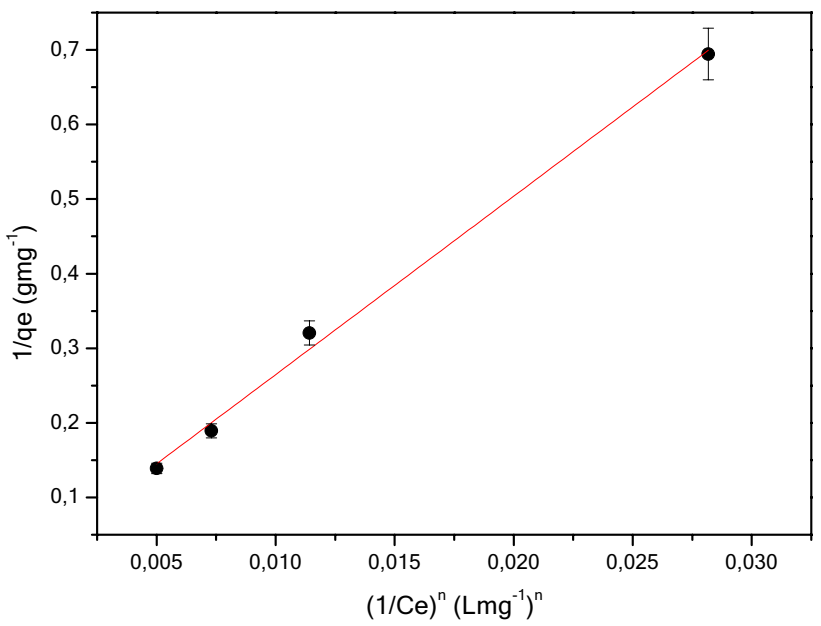

Fig. 14 Sips Isotherm, at $25^{\circ} \mathrm{C}$

the adsorbent surface is heterogeneous. This result coincides with the Freundlich isotherm results.

\subsubsection{Sips isotherm}

Sips Isotherm is a hybrid model combining the Freundlich and Langmuir isotherm models depending on $\mathrm{n}_{s^{\prime}}$ parameter [52]. When $n_{s}$ goes to unity, the Sips isotherm returns to the Langmuir model which indicates the homogeneous adsorption. Otherwise, the deviation of $n_{s}$ value from the unity represents heterogeneous surface. The Sips equation isotherm can be expressed as follows;

$q_{e}=\frac{q_{m}\left(K_{s} C_{e}\right)^{n_{s}}}{1+\left(K_{s} C_{e}\right)^{n_{s}}}$ 
where $\mathrm{K}_{\mathrm{S}}$ is the affinity constant $\left(\mathrm{L} \mathrm{mg}^{-1}\right)$ and $\mathrm{n}_{\mathrm{s}}$ represents the surface heterogeneity.

The parameters obtained from the Sips isotherm (Fig. 14) are shown in Table $5 . n_{s}$ value was calculated 1.4 and $R^{2}$ was found as 0.997 . The deviation of $n_{S}$ value from unity denotes the heterogeneity of the surface of the adsorbent. These results also support the results obtained in the Freundlich isotherm (Fig. 12).

\section{Conclusions}

In this study, the adsorption kinetics and adsorption isotherms of methyl orange on the untreated and treated halloysite mineral were systematically examined. After the modification process, the adsorption capacity of the halloysite mineral increased significantly and the maximum adsorption (\%) values of $80 \mathrm{ppm} \mathrm{MO}$ solution was obtained as $91 \%$ on modified halloysite. During the adsorption process, the $\mathrm{MO}$ solutions also became noticeably more clear and transparent in color, which indicate a reduction in the concentration of the solved dye. The pseudo second-order kinetics were suitable for describing the adsorption of $\mathrm{MO}$ on the unmodified and modified halloysite. Furthermore, the adsorption isotherm was found to be suitable with the Langmuir and Freundlich adsorption isotherms which relate to multi-layered heterogenous adsorption. The results obtained from the Sips isotherm support this conclusion. The surface heterogeneity value, 1.4 matches with these results. The modification of Halloysite has a positive contribution to the percentage of adsorption and adsorption capacity. The modified Halloysite clay has potential applications in the field of methyl orange treatment from aqueous solution.

Acknowledgements This work was supported by the Scientific Research Projects (BAP), coordination unit of Istanbul University, Project ID, 49703.

\section{Complaince with ethical standards}

Conflict of interest On behalf of all authors, the corresponding author states that there is no conflict of interest.

\section{References}

1. Rafatullah $M$, Sulaiman $O$, Hashim $R$, Ahmad A (2010) Adsorption of methylene blue on low-cost adsorbents: a review. J Hazard Mater 177(1-3):70-80

2. Hajjaji W, Andrejkovicova S, Pullar RC, Tobaldi DM, LopezGalindo A, Jammousi F, Rocha F, Labrincha JA (2016) Effective removal of anionic and cationic dyes by kaolinite and $\mathrm{TiO}_{2} / \mathrm{kao}-$ linite composites. Clay Miner 51(1):19-27
3. Mouni L, Belkhiri L, Bollinger JC, Bouzaza A, Assadi A, Tirri A, Dahmoune F, Madani K, Remini H (2018) Removal of Methylene Blue from aqueous solutions by adsorption on Kaolin: kinetic and equilibrium studies. Appl Clay Sci 153:38-45

4. Adegoke KA, Bello OS (2015) Dye sequestration using agricultural wastes as adsorbents. Water Res Ind 12:8-24

5. Kandisa RV, Saibaba NKV, Shaik KB, Gopinath RJ (2016) Dye removal by adsorption: a review. J Bioremed Biodegrad 7(6):1000371

6. Zhai L, Bai Z, Zhu Y, Wang B, Luo W (2018) Fabrication of chitosan microspheres for efficient adsorption of methyl orange. Chin Chem Eng J 26(3):657-666

7. Reck IM, Paix RM, Bergamasco R, Vieira MF, Vieira AMS (2018) Removal of tartrazine from aqueous solutions using adsorbents based on activated carbon and Moringa oleifera seeds. J Clean Prod 171:85-97

8. Sismanoglu T, Aroguz AZ (2015) Adsorption kinetics of diazodye from aqueous solutions by using natural origin low-cost biosorbents. Desalin Water Treat 54(3):736-743

9. Gong R, Ye J, Dai W, Yan X, Hu J, Hu X, Li S, Huang H (2013) Adsorptive removal of methyl orange and methylene blue from aqueous solution with finger-citron-residue-based activated carbon. Ind Eng Chem Res 52(39):14297-14303

10. Tariqul Islam M, Saenz-Arana R, Hernandez C, Guinto T, Ahsan AM, Bragg DT, Wang H, Alvarado-Tenorio B, Noveron JC (2018) Conversion of waste tire rubber into a high-capacity adsorbent for the removal of methylene blue, methyl orange, and tetracycline from water. J Environ Chem Eng 6(2):3070-3082

11. Kausar A, lqbal M, Javed A, Aftab K, Nazlı ZH, Bhatti HN, Nouren $S$ (2018) Dyes adsorption using clay and modified clay: a review. J Mol Liq 256:395-407

12. Seow TW, Lim CK (2016) Removal of dye by adsorption: a review. Int J Appl Eng Res 11(4):2675-2679

13. Yagub MT, Sen KT, Afroze S, Ang HM (2014) Dye and its removal from aqueous solution by adsorption: a review. Adv Colloid Interface Sci 209:172-184

14. Zhou Y, Zhang L, Cheng Z (2015) Removal of organic pollutants from aqueous solution using agricultural wastes: a review. J Mol Liq 212:739-762

15. Meenambal T, Devi D (2006) Colour removal from textile waste water using bioculture in continous mode. J Environ Chem Eng 48(4):247-252

16. Aroguz AZ, Sayili G (2016) The synthesis of silica-coated magnetic nanoparticles and using as adsorbent. Polym Bull 73(8):2353-2372

17. Mohamed M, Ali OS, Essam AM, Moaaz KS (2018) A superior adsorbent of $\mathrm{CTAB} / \mathrm{H}_{2} \mathrm{O}_{2}$ solution-modified organic carbon richclay for hexavalent chromium and methyl orange uptake from solutions. J Mol Liq 259:384-397

18. Tholiso N, Jabulani RG, Vhahangwele M, Arjun M (2017) An update on synthetic dyes adsorption onto clay based minerals: a state-of-art review. J Environ Manag 191:35-57

19. Hosseini AsI SM, Ghadi A, Baei MS, Javadian H, Kazemian H (2018) Porous catalysts fabricated from coal fly ash as costeffective alternatives for industrial applications: a review. Fuel 217:320-342

20. Abdel-Khalek MA, Abdel Rahman MK, Francis AA (2017) Exploring the adsorption behavior of cationic and anionic dyes on industrial waste shells of egg. J Environ Chem Eng 5(1):319-327

21. Abdelrahman EA (2018) Synthesis of zeolite nanostructures from waste aluminum cans for efficient removal of malachite green dye from aqueous media. J Mol Liq 253:72-82

22. Alpat SK, Ozbayrak O, Alpat S, Akçay H (2008) The adsorption kinetics and removal of cationic dye, Toluidine Blue $\mathrm{O}$, from aqueous solution with Turkish zeolite. J Hazard Mater 151(1):213-220 
23. Mirzaei N, Ghaffari HR, Sharafi K, Velayati A, Dindarloo K (2017) Modified natural zeolite using ammonium quaternary based material for Acid red 18 removal from aqueous solution. J Environ Chem Eng 5(4):3151-3160

24. Berthier P (1826) Analyse de I' halloysite. Ann Chim Phys 32:332-334

25. Laçin D (2003) Bedding characteristics, mineralogy and formations of halloysites of Biga Peninsula (Çanakkale-Balıkesir) (In Turkish). PhD thesis, University of Istanbul Science, Turkey

26. Ross CS, Kerr PF (1935) Halloysite and allophane. US Geol Sur Profess Paper 185-G:148

27. Zeng GY, Ye ZB, He Y, Yang X, Ma J, Shi H, Feng ZL (2017) Application of dopamine-modified halloysite nanotubes/PVDF blend membranes for direct dyes removal from wastewater. Chem Eng J 323:572-583

28. Chen H, Yan H, Pei Z, Wu J, Li R, Jin Y, Zhao J (2015) Trapping characteristic of halloysite lumen for methyl orange. Appl Surf Sci 347:769-776

29. Lazzara G, Cavallaro G, Panchal A, Fakhrullin A, Stavitskaya A, Vinokurov V, Lvov Y (2018) An assembly of organic-inorganic composites using halloysite clay nanotubes. Curr Opin Coll Interface Sci 35:42-50

30. Cavallaro G, Chiappisia L, Pasbakhshd P, Gradzielskia M, Lazzara G (2018) A structural comparison of halloysite nanotubes of different origin by small-angle neutron scattering (SANS) and electric birefringence. Appl Clay Sci 160:71-80

31. Cavallaro G, Lazzara G, Milioto S, Parisi F (2015) Hydrophobically modified halloysite nanotubes as reverse micelles for water-inoil emulsion. Langmuir 31:7472-7478

32. Cavallaro G, Grillo I, Gradzielski M, Lazzara G (2016) Structure of hybrid materials based on halloysite nanotubes filled with anionic surfactants. J Phys Chem C 120:13492-13502

33. Liu L, Wan Y, Xie Y, Zhai R, Zhang B, Liu J (2012) The removal of dye from aqueous solution using alginate-halloysite nanotube beads. Chem Eng J 187:210-216

34. Lu Z, Huang ZH, Feiyu Kang F (2011) Chemisorption of hydrogen sulfide on halloysite-based porous clay heterostructures modified with potassium permanganate. Asia Pac J Chem Eng 6:879-885

35. Liu R, Fu K, Zhang B, Mei D, Zhang H, Liu J (2012) Removal of methyl orange by modified halloysite nanotubes. J Dispers Sci Technol 33(5):711-718. https://doi.org/10.1080/01932 691.2011 .579855

36. Lázaro BB (2015) Halloysite and kaolinite: two clay minerals with geological and technological importance. Rev Real Academia de Ciencias Zaragoza 70:7-38

37. Hillier S, Ryan PC (2002) Identification of halloysite (7Å) by ethylene glycol solvation: the "MacEwan effect". Clay Miner $37: 487-496$
38. Lim S, Park S, Sohn D (2020) Modification of halloysite nanotubes for enhancement of gas-adsorption capacity. Clay Clay Miner 68(3):189-196

39. El Haddar A, Gharibi E, Azdimousa A, Fagel N, Iz-Eddine EAEH, El Ouahabi M (2018) Characterization of halloysite (North East Rif, Morocco): evaluation of its suitability for the ceramics industry clay minerals. Clay Miner 53(1):1-43

40. Kadi S, Lellou S, Marouf-Khelifa K, Schott J, Gener-Batonneau I (2012) Amine Khelifa preparation, characterisation and application of thermally treated Algerian Halloysite. Microporous Mesoporous Mater 158:47-54

41. Frost RL, Vassalo MA (1996) The dehydroxylation of the kaolinite clay minerals using infrared emission spectroscopy. Clay Clay Miner 44(5):635-651

42. Pasbakhsh P, Jock Churchman G, Keeling JL (2013) Characterisation of properties of various halloysites relevant to their use as nanotubes and microfibre fillers. Appl Clay Sci 74:47-57

43. Lagergren $S$ (1898) Zur theorie der sogenannten adsorption geloster stoffe. K Sven Vetensk Handl 24(4):1-39

44. Ho YS, McKay G (1999) Pseudo-second order model for sorption processes. Process Biochem 34(5):451-465

45. Weber WJ, Morris JC (1963) Morris, kinetics of adsorption on carbon from solution. J Sanit Eng Div Am Soc Civil Eng 89:31-60

46. Langmuir I (1918) The adsorption of gases on plane surfaces of glass, mica and platinum. J Am Chem Soc 40(9):1361-1403

47. Robati D, Mirza B, Rajabi M, Moradi O, Tyagi I, Agarwal S, Gupta VK (2016) Removal of hazardous dyes-BR 12 and methyl orange using graphene oxide as an adsorbent from aqueous phase. Chem Eng J 284:687-697

48. Freundlich HMF (1906) Uber die adsorption in losungen. $Z$ Phys Chem 57A:385-470

49. Polanyi M (1932) Section 111.- Theories of the adsorption of gases. A general survey and some additional remarks. Trans Faraday Soc 28:316

50. Dubinin MM, Radushkevich LV (1947) The equation of the characteristic curve of the activated charcoal. Proc Acad Sci USSR Phys Chem Sect 55:331-337

51. Hu Q, Zhang Z (2019) Application of Dubinin-Radushkevich isotherm model at the solid/solution interface: a theoretical analysis. J Mol Liq 277(2019):646-648

52. Sips R (1948) The structure of a catalyst surface. J Chem Phys 16:490-495

Publisher's note Springer Nature remains neutral with regard to jurisdictional claims in published maps and institutional affiliations. 